九州大学学術情報リポジトリ

Kyushu University Institutional Repository

\title{
Fundamental Study of Stope and Barrier Pillar Stabilities by Using Cut and Fill Method for Redevelopment of Rest Gold Mine, Myanmar
}

NAUNG, Naung

Department of Earth Resources Engineering, Faculty of Engineering, Kyushu University

Shimada, Hideki

Department of Earth Resources Engineering, Faculty of Engineering, Kyushu University : Professor

Sasaoka, Takashi

Department of Earth Resources Engineering, Faculty of Engineering, Kyushu University : Associate Professor

Hamanaka, Akihiro

Department of Earth Resources Engineering, Faculty of Engineering, Kyushu University : Assistant Professor

他

http://hdl. handle. net/2324/4355472

出版情報: Proceedings of the 27th International Symposium on Mine Planning and Equipment Selection, pp. 35-53, 2019-02-22. Springer Nature

バージョン :

権利関係 : 


\title{
Fundamental Study of Stope and Barrier Pillar Stabilities by Using Cut and Fill Method for Redevelopment of Rest Gold Mine, Myanmar
}

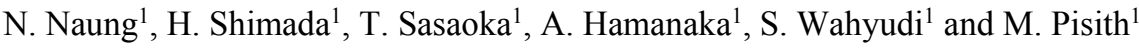 \\ ${ }^{1}$ Department of Earth Resources Engineering, Kyushu University, Japan \\ Email of Corresponding author: naung15r@mine.kyushu-u.ac.jp
}

\begin{abstract}
The stability of mine development is very important during the planned period of production. Additionally, it would be a great challenge for redeveloping rest mine project to extend the mine area due to the effect of previous mined-out area. The deposits of rest mine are usually located in deeper regions; accordingly, stress condition will be greatly changed. The existence of underground water from previous mined-out area is also possible to infiltrate into the redevelopment of rest mine area which will influence the stability of new openings. This paper describes the stability design of a redevelopment of a rest mine, with National Prosperity Gold Production Group Limited (NPGPGL) underground gold mine in Myanmar as a case study. This mine adopts overhand cut and fill method to extract the minerals. NPGPGL is characterized with steeply dipping vein with complex fractures and underground water, particularly during rainy season. NPGPGL has been developing stopes up to $150 \mathrm{~m}$ from the surface, and the mining activities are going to continue to deeper levels by introducing redevelopment rest mine project. Redevelopment of rest mine is not easy considering the instability can rise at new stope opening not only due to its own induced stress but also the effect of previous mined-out area. Therefore, suitable countermeasure arrangements are paramount to be prepared by considering the stability of stope. To determine the stability of stope and barrier pillar design of new opening, numerical simulations was carried out by using 3D finite difference software (FLAC 3D).
\end{abstract}

Keywords: Cut and fill stoping, FLAC3D, Instability, Redevelopment, Rest Gold Mine

\section{Introduction}

Mineral consumption is gradually increasing as the global standard of living increases and mineral demand will be largely concentrated in developing countries experiencing economic development progressively. This implies mineral extraction from greater depths both surface mining and underground mining. However, underground mining will become more important in coming decades as environmental issues make surface mining less attractive. After a period of mining, easily accessible shallow mineral resources are being mined out and the deposits of 
rest mine are left in deeper regions. Therefore, underground mining continues to progress into deeper levels in order to fulfill the mineral supply. Accordingly, stress condition in deeper mine will be greatly changed and the mining process would be more complicated when it is operated for redevelopment of rest mine projects. Without doubt, stability of underground openings is a major concern for the safety and productivity of mining operations. Mine development instability can result in production delays, loss of reserves, as well as damage to equipment, and injuries. Therefore, this paper outlines the fundamental study of stope and barrier pillar stabilities for the redevelopment of rest gold mine, National Prosperity Gold Production Group Limited (NPGPGL) underground gold mine in Myanmar, as a case study.

The instability of underground excavation depends on the behaviors of the surrounding rock mass. Different rock types have different characteristics parameters that influence their mechanical behaviors. Therefore, knowledge and understanding of rock mass condition are essential for stability of underground excavations. The first step for describing rock mass is to examine rock mass properties determined by lithology, laboratory tests and field observation data. The second step is to determine the geotechnical information of rock mass for the purpose of rock engineering design such as numerical modelling, analytical calculation, etc. Considering the importance of rock stability in stope opening, field observation for lithology, geology and mining system at NPGPGL underground gold mine was conducted, and laboratory experiments was carried out to get the physical properties of rock mass, and fundamental study was carried out by using numerical simulations.

\section{Introduction}

\section{$2.1 \quad$ Location}

NPGPGL at Modi Taung is situated approximately $150 \mathrm{~km}$ southeast of Mandalay and $385 \mathrm{~km}$ north of Yangon, in the eastern part of the Yamethin Township, central Myanmar as shown in Fig. 1. The company is operating in the southern part of Block 10 area where the exploration works were previously conducted by Ivanhoe Myanmar Holding Ltd. (IMHL), a Canadian mining company, who acquired the exploration/mining lease from the government from August 1996 to August 2005. NPGPGL started this gold mine on September 2011 with total mine lease area of $24.71 \mathrm{~km}^{2}$. The mine is located approximately $1300 \mathrm{~m}$ above sea level and it takes around three hours from Nay Pyi Taw, capital city of Myanmar by car and the road conditions vary from sealed roads to off roads.

\subsection{Regional Geology}

Block 10 concession in central Myanmar has identified a $100 \mathrm{~km}^{2}$ gold district, the Modi Taung - Nankwe district, with feature characteristic of slate-hosted 
mesothermal quartz-gold vein deposits as shown in Fig. 2. The deposit is hosted in the sedimentary units of the Mergui Group, which is composed of two dominant sedimentary formations. The lower part consists of massive to laminated mudstone, sandstone, rare limestones and channel-fill pebbly wackes while the upper part includes several polymict conglomerates [1].

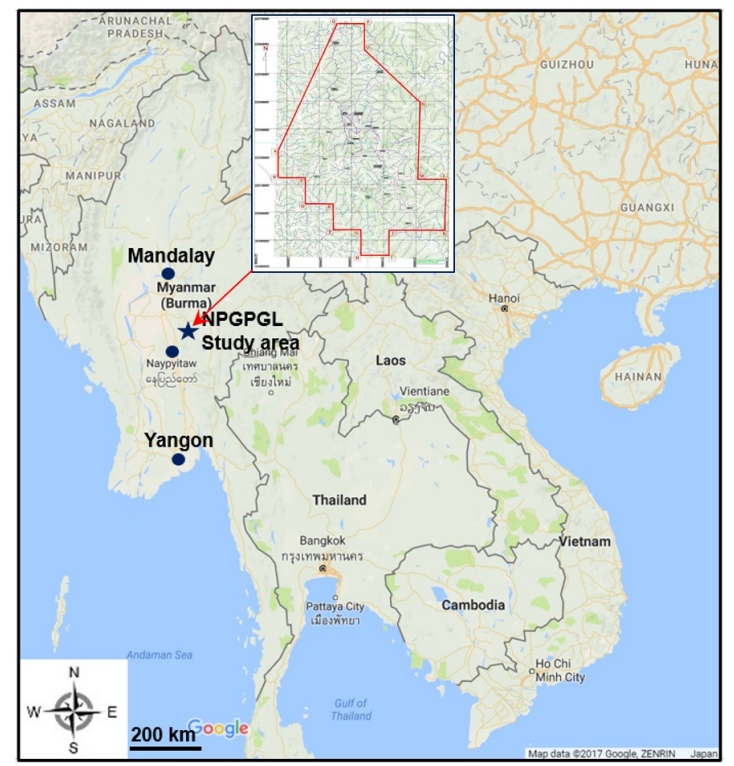

Fig. 1. Research mine site's location map.

\subsection{Host Rock Lithology of NPGPGL}

Veins at Modi Taung gold mine are hosted by four main lithologies: mudstone, sandstone-siltstone, limey sandstone or limestone, and igneous intrusions. Mudstones are the predominant rock type in all vein system but sandstone occupies short segments, and veins tend to occur along the inclined interface between sandstone and mudstone. Their competence and hardness increase with depth from soft clay immediately beneath soil cover to a hard rock that is tough and competent with the exception of moderate hardness near and below the base of the oxide zone. Sandstone and siltstone are mostly silicified and cut by quartz stockworks, forming quartzite. They are mostly intensely fracture, and hence brittle. Ground conditions are poor in Shwesin vein system and within $60 \mathrm{~m}$ from surface where partial oxidation has occurred [2].

At NPGPGL gold mine, Htongyi Taung and Sakangyi vein systems are hosted by mudstone, while in the Shwesin, Sakangyi and Momi Taung systems host rocks are predominantly mudstone or siltstone and the rest sandstone [1]. Veins in east of the 
least area are dipping steeply to the west, while veins in the west are dipping steeply to the east. Vein width varies with elevation and ranges between centimeter and meter scale [3]. The detail geological structure of NPGPGL is shown in Fig. 3.

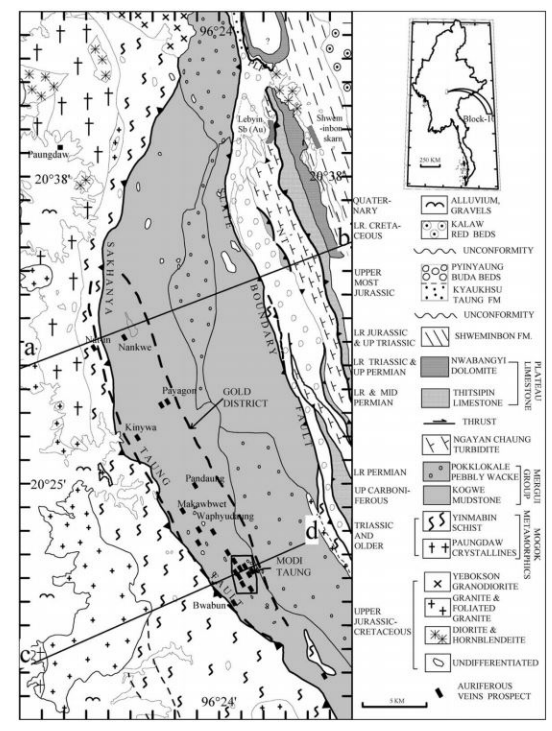

Fig. 2. Simplified geology map of Block 10 concession [1].

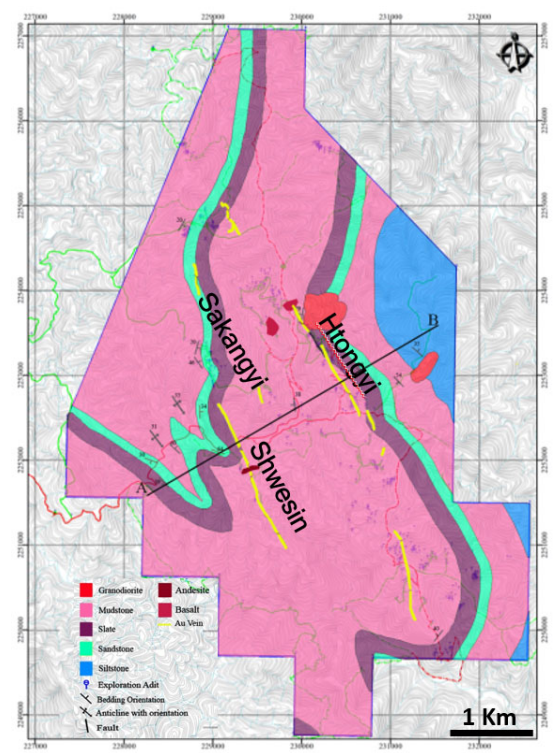

Fig. 3. Geological map of NPGPGL [3]. 


\section{Field Observation}

\subsection{Rock Mass Condition}

Currently, most of the shallow parts of NPGPGL are already mined out and mining activities are going to continue to progress to deeper levels in order to fulfill the target ore production. Therefore, rock mass condition at deeper area should be investigated for stability of underground excavations. From the borehole data, the RQD and depth from NPGPGL gold mine are shown in Fig. 4 and the correlation between RQD percentage and rock mass quality is shown in Table 1. According to the RQD data, the rock mass of NPGPGL can be classified as fair condition and some activities such as discontinuities, persistence, aperture, rock roughness, and weathering of rock are conducted to complete full estimation of rock mass condition. Furthermore, rock mass parameters that obtained from laboratory experiments are shown in Table 2 and the uniaxial compressive strength of intact host rock and vein from NPGPGL gold mine are $148 \mathrm{MPa}$ and $140 \mathrm{MPa}$, respectively.

According to these intact rock parameters, it can be seen that the rock mass strength from NPGPGL gold mine is too strong. However, without the consideration of geological structure, rock mass properties are not properly applicable for any form of analysis for the design of slopes and underground excavations. Regarding this case, the Geological Strength Index (GSI) introduced by Hoek, E., Kaiser, P.K. and Bawden, 2000 [4] is very essential to estimate the rock mass strength for different geological conditions. From the field observation at NPGPGL gold mine, many cracks and joints within rock mass are found in underground tunnels and stopes as shown in Fig. 5. Additionally, heavy rainfall is one of the causes of weathering of rock mass. The rate of water charge increases after periods of heavy rain which is common for this area. This meteoric water interacts with the surrounding rocks which result in weathering of host rocks, leading to strength reduction of host rocks. All of these conditions will give effect to the instability of underground excavations and should be paid attention in order to prevent the ground collapse.

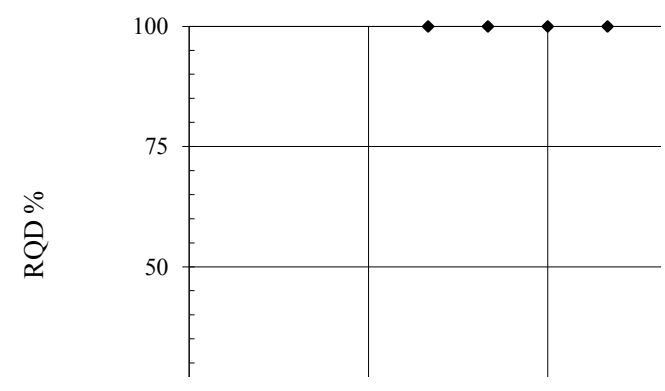

Fig. 4. Relation between RQD and depth of NPGPGL gold mine. 
Table 1. RQD classification index.

\begin{tabular}{ll}
\hline RQD & Rock mass quality \\
\hline$<25 \%$ & Very poor \\
$25-50 \%$ & Poor \\
$50-75 \%$ & Fair \\
$75-90 \%$ & Good \\
$90-100 \%$ & Excellent \\
\hline
\end{tabular}

Table 2. Intact rock properties obtained from laboratory experiments.

\begin{tabular}{lllllll}
\hline & $\rho\left[\mathrm{kg} / \mathrm{m}^{3}\right]$ & $E[\mathrm{MPa}]$ & $v[-]$ & $\sigma_{t}[\mathrm{MPa}]$ & $\varphi[\mathrm{deg}]$ & $C[\mathrm{MPa}]$ \\
\hline Host rock & 2717 & 19000 & 0.25 & 10.4 & 58 & 18.5 \\
Vein & 2667 & 12000 & 0.22 & 3.8 & 71 & 11.1 \\
\hline
\end{tabular}
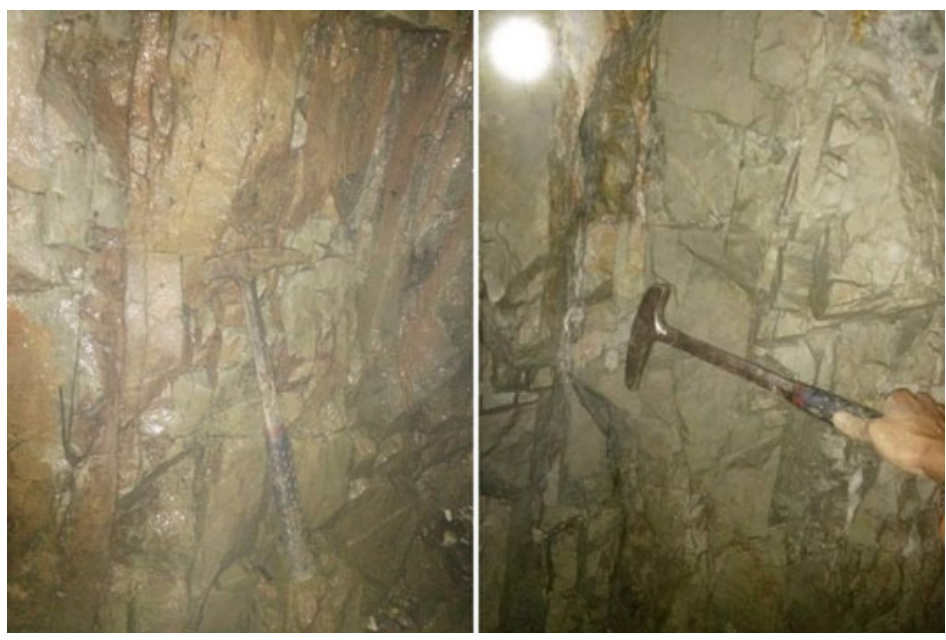

Fig. 5. Rock mass condition in underground tunnel showing joints and cracks.

Consideration of rock mass condition including several factors such as RQD, joint spacing, condition of joints, and weathering, the evaluation of NPGPGL rock mass properties from intact rock properties are shown in table 3.

Table 3. Rock mass properties evaluated with geological conditions.

\begin{tabular}{lcccccc}
\hline & $\rho\left[\mathrm{kg} / \mathrm{m}^{3}\right]$ & $E[\mathrm{MPa}]$ & $v[-]$ & $\sigma_{t}[\mathrm{MPa}]$ & $\varphi[\mathrm{deg}]$ & $C[\mathrm{MPa}]$ \\
\hline Hanging wall & 2670 & 3786 & 0.23 & 0.035 & 42 & 0.904 \\
Foot wall & 2717 & 3786 & 0.25 & 0.065 & 38 & 0.806 \\
Vein & 2667 & 3374 & 0.22 & 0.028 & 42 & 0.871 \\
\hline
\end{tabular}




\subsection{Mining System}

As described above, the accessible shallow area is already mined out at NPGPGL and the deposits of rest mine are left in deeper regions. Therefore, the company is planning to mine out the deeper area at Shwesin vein which are separated into 6 blocks, namely from block 1 to block 6. The overall mine plan is illustrated in Fig. 6 .

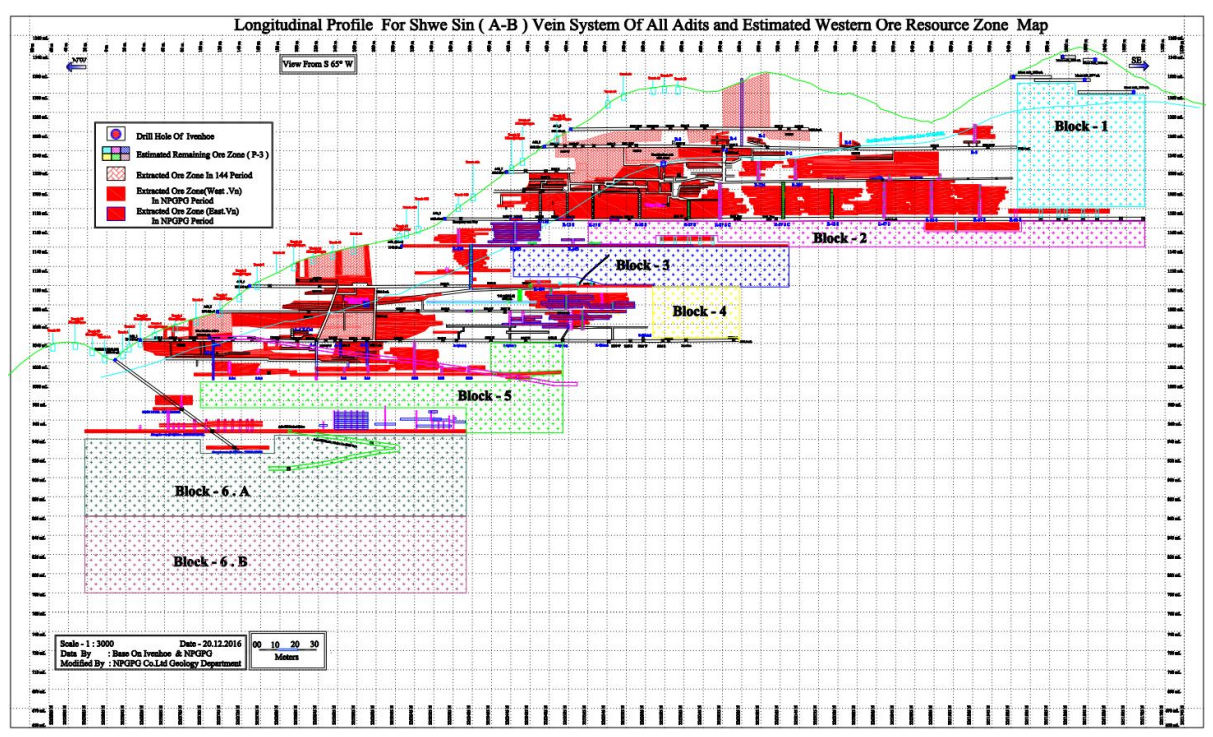

Fig. 6. Mine plan at Shwesin vein system (Source: NPGPGL).

The company adopts open stope mining and overhand cut and fill method to extract the minerals at Shwesin vein system. The waste rocks from excavation are only using to both fill the stope and provide permanent wall support for the lower mine out cavity. Vein width varies with elevation and ranges between centimeter and meter scale. Vein dipping are more than 50 degree, and Vein orientation within Shwesin vein system and vein widths with elevation at NPGPGL gold mine area are shown in Figs. 7 and $8[3]$.

\section{Numerical Modeling for NPGPGL Gold Mine}

The stability of stope and barrier pillar for redevelopment of rest gold mine in deeper regions at NPGPGL was carried out in different numerical models by using the FLAC 3D code. FLAC 3D is explicit finite difference code that is developed for analyzing stress and deformation of mining and tunneling problems conducted in both soil and rock. In this paper, the numerical simulations were modelled in order to understand the failure conditions of new stope opening due to the effects of previous mined-out area, the stability analysis considering different barrier pillars size $(2 \mathrm{~m}$, 
$2.5 \mathrm{~m}, 3 \mathrm{~m}, 3.5 \mathrm{~m}$ ) and various vein dips (60 degree, 70 degree and 80 degree). All the numerical models size are $250 \mathrm{~m} \times 250 \mathrm{~m}$ x $250 \mathrm{~m}$ as shown in Fig. 9. As described in host rock lithology of NPGPGL, the slaty mudstone is a dominant rock type in the NPGPGL gold mine, and therefore, the hanging wall and footwall are assigned as homogenous model for simplification. The mechanical properties of host rock and vein are given in Table 3. Moreover, to obtain more precise result of the rock failure distribution, the smaller mesh size was selected around the excavation area.

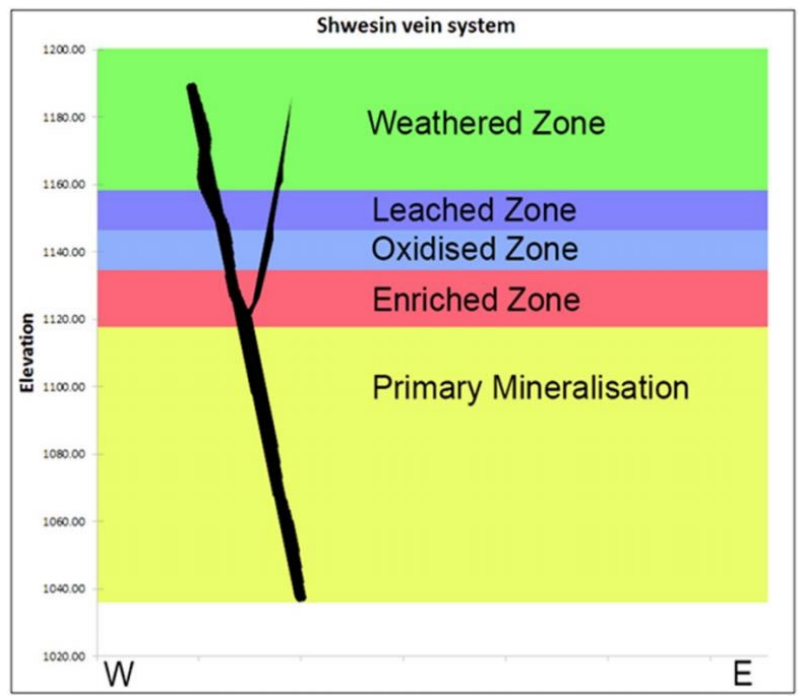

Fig. 7. Shwesin vein orientation system [3].

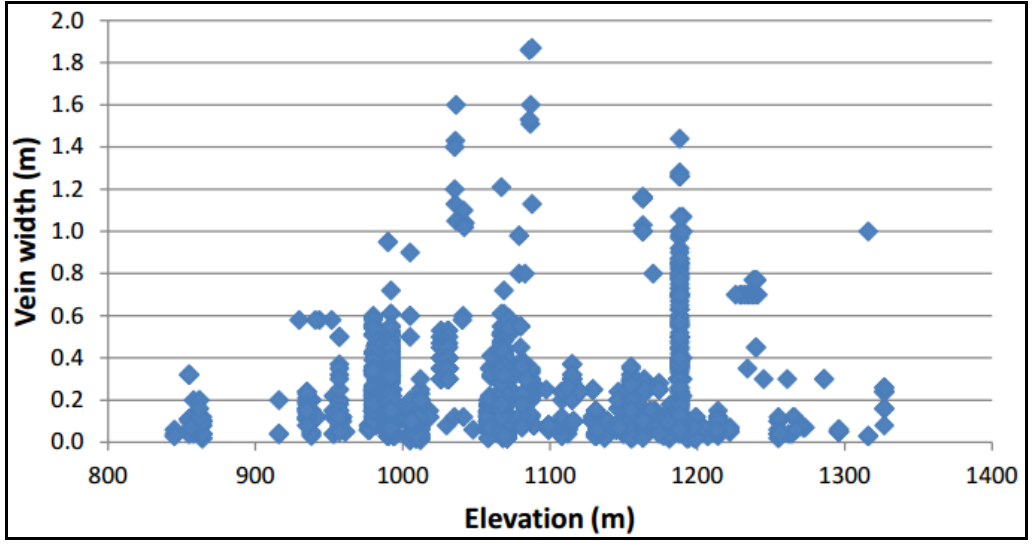

Fig. 8. Vein widths plotted against elevations at NPGPGL gold mine [3]. 


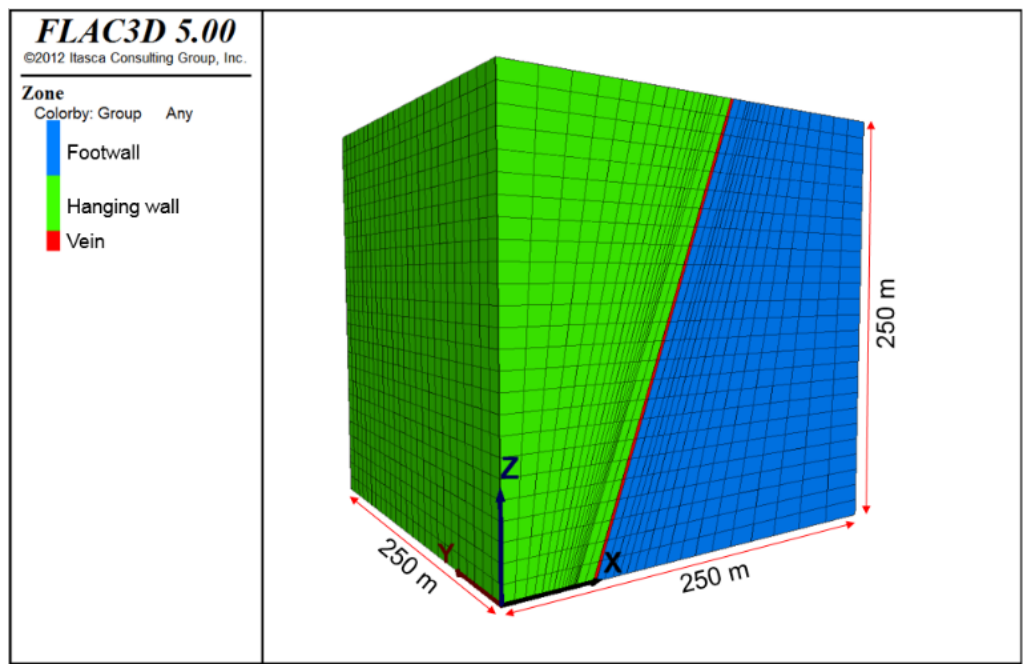

Fig. 9. Numerical model.

\subsection{Case Study}

In this research, the case study from Shwesin vein system at NPGPGL gold mine is presented for the overhand cut and fill mining from the lower slice of the vein of block 2 as shown in Fig. 10. Block 2 is the planned mine area with $24 \mathrm{~m}$ height that is assigned between adit 5 and adit 8 of Shwesin vein. The previous mined-out area with $100 \mathrm{~m}$ height is overlaying above the block 2 and the total overburden above block 2 is $150 \mathrm{~m}$. This case study is investigated for the stability of current stope opening in block 2 not only due to its own induced stress but also the effect of overlaying minedout area. The stope dimension is $2.5 \mathrm{~m}$ in height and $2 \mathrm{~m}$ in width and the stoping sequence takes place from the lower slice to upwards direction. During the stope mining, the waste rocks from excavation are used to fill the stope and it provides a working platform for the miners when the next slice is mined. For preparing stope arrangements, steep compartment wooded raises are developed from the main roadway to provide ore/waste passes and manways.

\subsection{Failure Evaluation Criterion}

Mining objective is to recover as much ore as possible from the vein. However, men and machines work in the advancing stopes and their safety must be ensured. Potential hazards in the stopes are rock falls from the stope's roof and buckling failures in the hanging wall and footwall. In order to stabilize the stope, a failure criterion must be selected. A common problem in mine excavation engineering is estimating the stability of designed stope to achieve minimum required value of Factor of Safety under which roof and wall are considered as unstable. A factor of 
safety of 1.3 would generally be considered for a temporary mine opening while a value of 1.5 to 2.0 may be required for a permanent excavation [4]. The selection of an appropriate factor of safety is based upon engineering experience and field observation. In this research, the Mohr-Coulomb failure criterion is adopted as shown in Fig. 11 and elasto-plastic behavior of the rock mass is used.

Cross-section view of mine out area
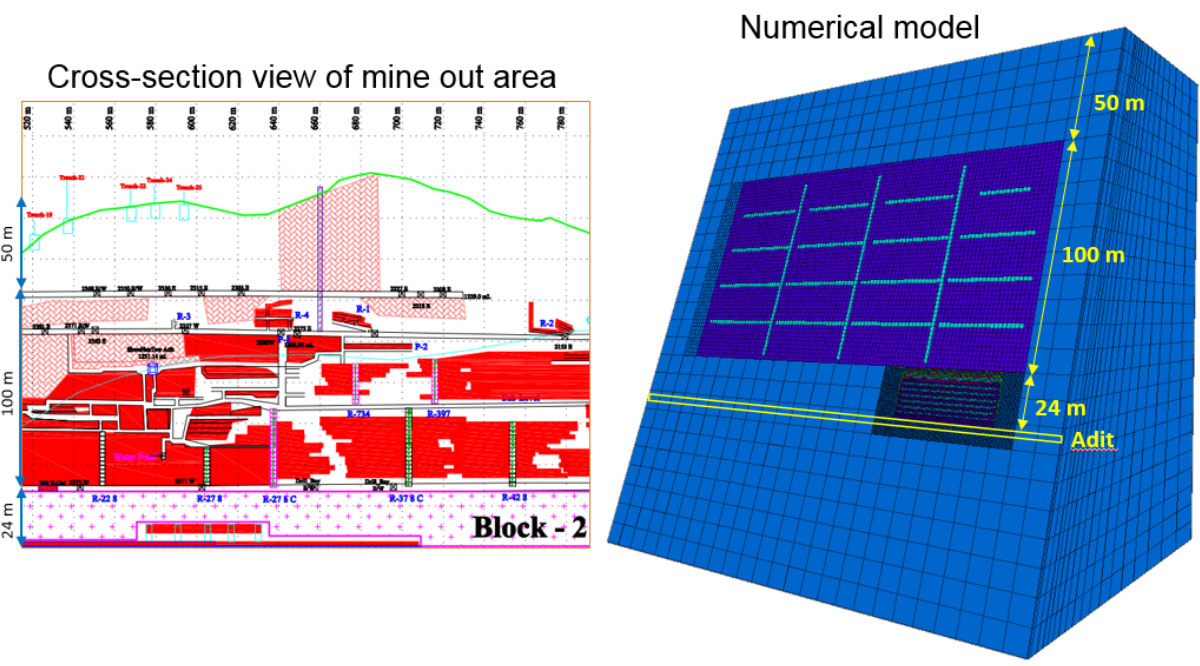

Fig. 10. Overhand cut and fill mine plan at Block 2 at Shwesin vein.

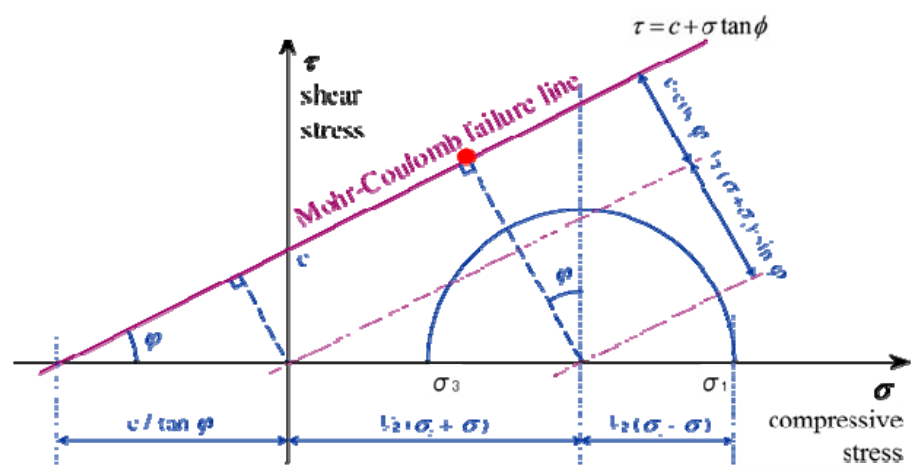

Fig. 11. Mohr-Coulomb failure criterion.

The strength factor (factor of safety) is calculated by dividing the strength of rock mass by the induced stress of stoping activities to provide a basis of stability assessment as follows: 
Strength factor $=$ Rock mass strength $/$ induced stress $=\left\{c \cos \varphi+\left[\left(\sigma_{1}+\sigma_{3}\right) / 2 \times\right.\right.$

$\sin \varphi]\} /\left[\left(\sigma_{1}+\sigma_{3}\right) / 2\right]$.

Strength factor (safety factor) of 1.3 is adopted for temporary stope mining. The stope was considered to be in a stable condition when Mohr-Coulomb strength factor is greater than 1.3. On the other hand, the failure of stope is assumed to occur when strength factor is less than 1 , and the unstable condition was assigned between the strength factor value 1 and 1.3.

\subsection{Result and Discussions}

Redevelopment process of new open stoping under previous mining regions can affect in high levels of unplanned dilution around the stope room not only due to blast-induced over-break but also the stress redistribution of the overlaying mined-out regions. In general, no one can estimate the rock mass is stable or not without numerical simulations. Determining the tunnels and stopes are stable or unstable should be based on yield zones from numerical simulations. Thus, numerical simulations using FLAC3D have been observed to understand the effect of previous mined-out regions, the stability of barrier pillars with different heights and the failure condition of stope opening due to various vein dips. The explanations of failure terms given in the legend in Flac3D are as follows:

(i) "none" indicates no-failure zone,

(ii) "shear-n" indicates the region failed under shear loading and failure process is still in progress,

(iii) "shear-p" indicates the region failed under shear loading and failure process is stopped due to lowered amount of shear forces.

(iv) "tension-n" indicate the region failed under tensile loading, and failure process is still in progress,

(v) "tension-p" indicate the region failed under tensile loading, and failure process is stopped due to lowered amount of tensile forces.

\subsubsection{Effects of previous mined out regions at Shwesin vein system}

First of all, numerical simulations are carried out with the aim to understand the failure zone and stability of stope due to the effects of previous mined-out regions. Stope mining activities from numerical simulations are modelled from the lower slice of the vein to upwards direction and the mined-out stope is backfilled by using waste rock from excavation. Fig. 12 shows the failure zone which occurred around the stope without previous mining effects and Fig. 13 shows the failure zone developed with previous mining effects. Based on the simulation results of Fig. 12, the failure zone around the stope is increasing steadily as the stope progressing move towards upper slices. These trends tell that failure zone of current stope is accumulated to the next stope. Compared with the failure condition with the previous upper mined out effects as shown in Fig. 13, the failure characteristics of surrounding rock masses in Fig. 13 results are larger than those in Fig. 12. The statement can be drawn from these two 
results that the redistributed stresses from upper mined-out regions are surely propagated to the current stope mining activities. As a result, the development of failure zone of current stope room is increased not only due to its own induced stress but also the redistributed stresses of previous mined-out regions.

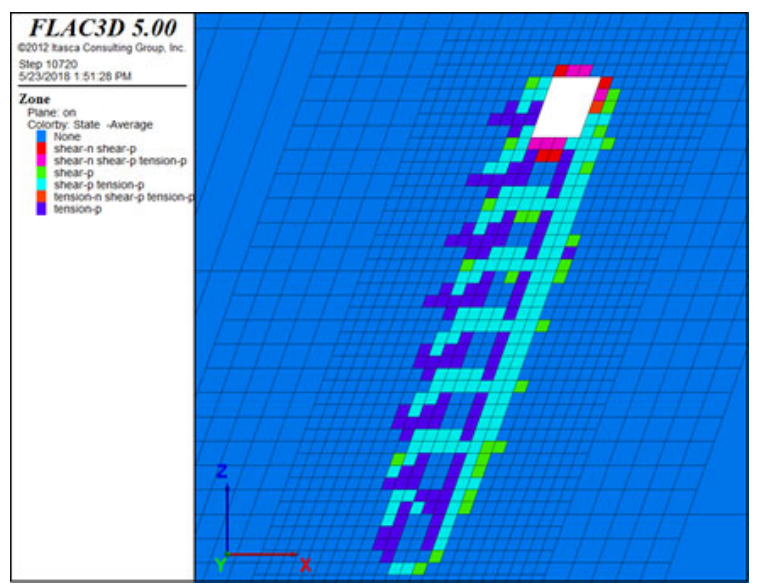

Fig. 12. Failure zone developed without previous mining effects.

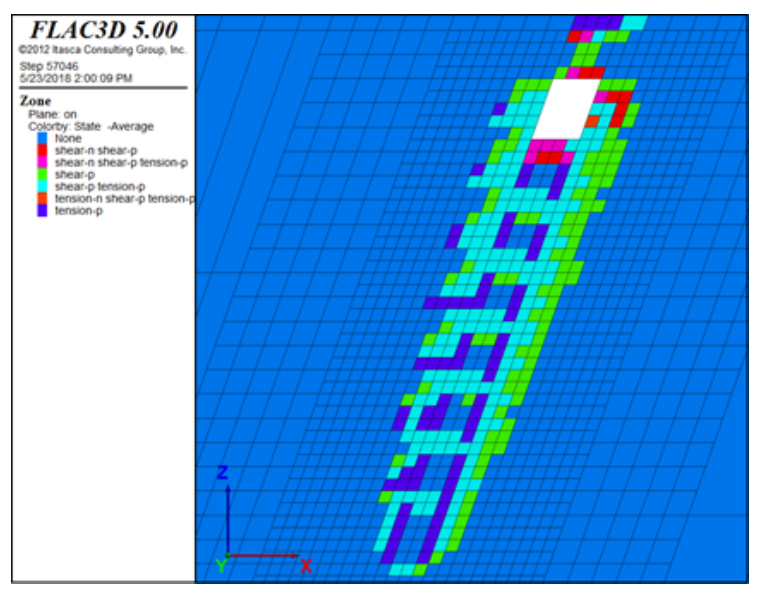

Fig. 13. Failure zone developed with previous mining effects.

It can be clearly seen in Figs. 14 and 15 that show the increasing unstable regions of current stope with the contour color code as mining activities continued into the upper slices. These results tell that decreasing strength factor makes increasing the unstable regions around the stope opening. Fig. 16 proved this description that strength factor indicator is gradually decreasing as the mining steps increase. The monitoring point for these indicators is placed $0.5 \mathrm{~m}$ above the center of stope's roof. 
Additionally, it can also be seen that the instability of the barrier pillar at uppermost stope with the effects of previous mined-out regions became more severe when the stope mining reaches to the uppermost level (i.e. nearest stope to the upper mined-out regions). In this simulation, this barrier pillar is set to be $2 \mathrm{~m}$ between the final stope and upper mined-out regions. Therefore, the numerical simulations for the stability of barrier pillar are conducted to understand the possibility of unstable regions with different barrier pillars and determine the appropriate barrier pillar to avoid rock falls from the stope's roof.

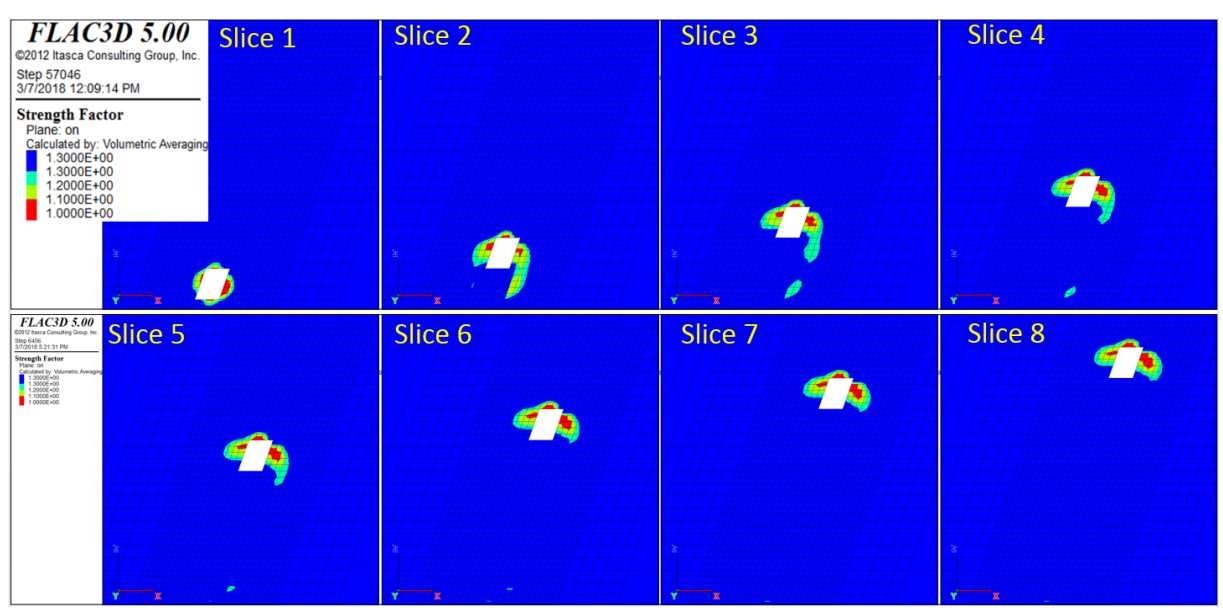

Fig. 14. Contour color of unstable area without the effect of previous mined-out regions.

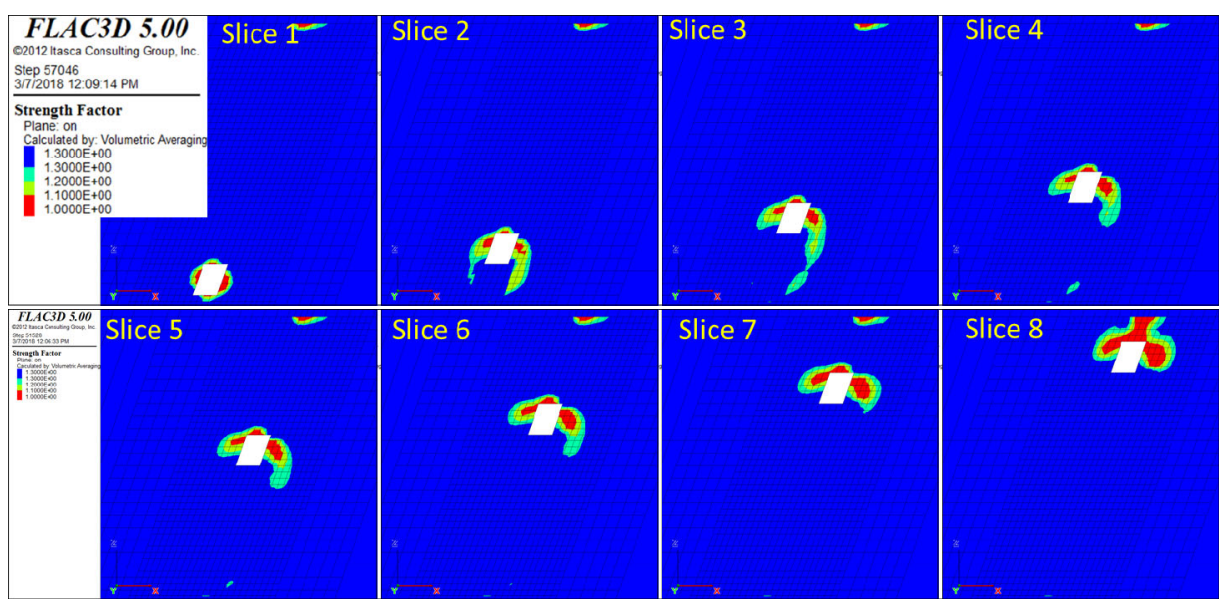

Fig. 15. Contour color of unstable area with the effect of previous mined-out regions. 


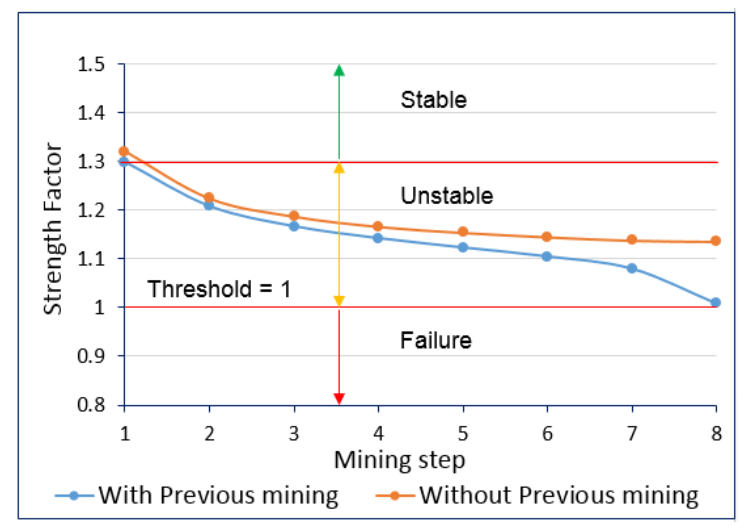

Fig. 16. Strength factor indicators at various mining steps.

\subsubsection{Stability of barrier pillars with the effects of overlaying mined out regions}

At Shwesin vein system from NPGPGL underground gold mine, the barrier pillar is broadly maintained $2 \mathrm{~m}$ between the top stope and overlaying mined-out regions. As explained in previous section, the failure zone at the uppermost barrier pillar propagated to overlaying mined-out regions. Therefore, numerical simulations with different barrier pillar heights $(2 \mathrm{~m}, 2.5 \mathrm{~m}, 3 \mathrm{~m}$ and $3.5 \mathrm{~m})$ was carried out in order to learn the stability of the barrier pillar of top stope. Fig. 17 shows that the failure condition of barrier pillar with different pillar heights and Fig. 18 indicates the unstable regions around the stope room shown by contour color code of strength factor. It can be seen that the failure zones and instability of top stope continue to the overlaying mined-out regions when the barrier pillar is set $2 \mathrm{~m}$ height, and decrease gradually when the barrier pillar increase to $2.5 \mathrm{~m}, 3 \mathrm{~m}$ and $3.5 \mathrm{~m}$ height, respectively. According to these results, it can be seen that the unstable regions is still propagated to the upper mined out failure zone when the barrier pillar height is set to $2.5 \mathrm{~m}$ height. However, this condition did not apply when the barrier pillars are $3 \mathrm{~m}$ and $3.5 \mathrm{~m}$ height. Therefore, these results suggested that the barrier pillar between the top stope and overlaying mined-out regions should be maintained at least $3 \mathrm{~m}$ height in order to make sure to stabilize the stope and to prevent rock falls from the stope's roof and walls.

\subsubsection{Instability due to the effect of various vein dips}

Many mineral deposits can occur as steeply dipping narrow veins. As described above, vein dipping is more than 50 degree in this mine site. Numerical simulations with vein dip of 60 degree, 70 degree and 80 degree are carried out to understand stope and barrier pillar stability in various vein dips. The results of these simulations 
are given in Fig. 19 and Fig. 20. The result from Fig. 19 suggests that the failure conditions are more likely to occur with low vein dip especially in hanging wall and foot wall. On the other hand, the failure zones above the stope opening increase as the vein dip increase. Fig. 20 shows the contour color code of unstable regions around the stope due to various vein dips. It can be seen clearly that the unstable regions are more severe in hanging wall and foot wall with lower vein dip while the instability become more develop above the stope opening with steeper vein dip.

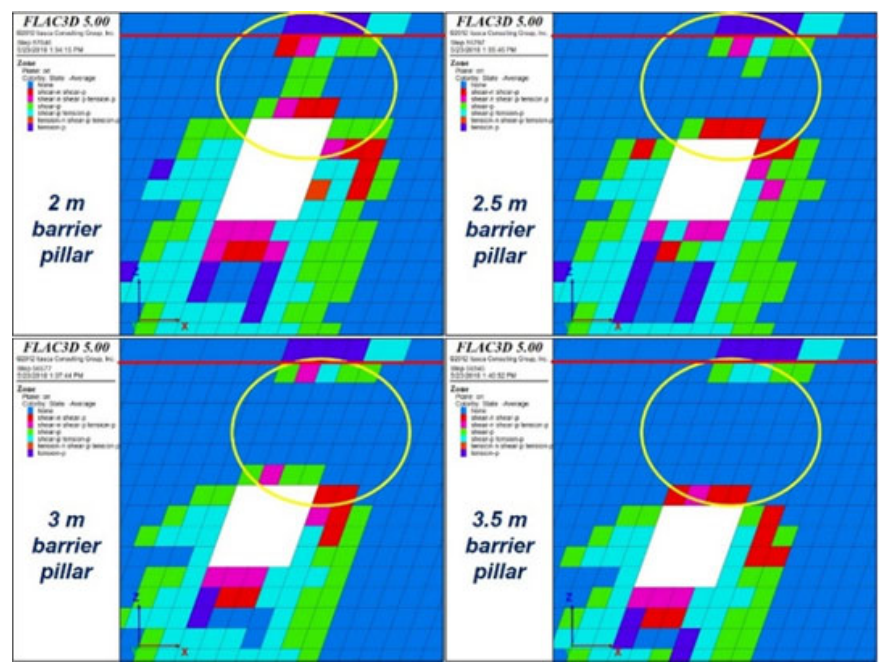

Fig. 17. Failure condition of barrier pillar with different pillar heights.

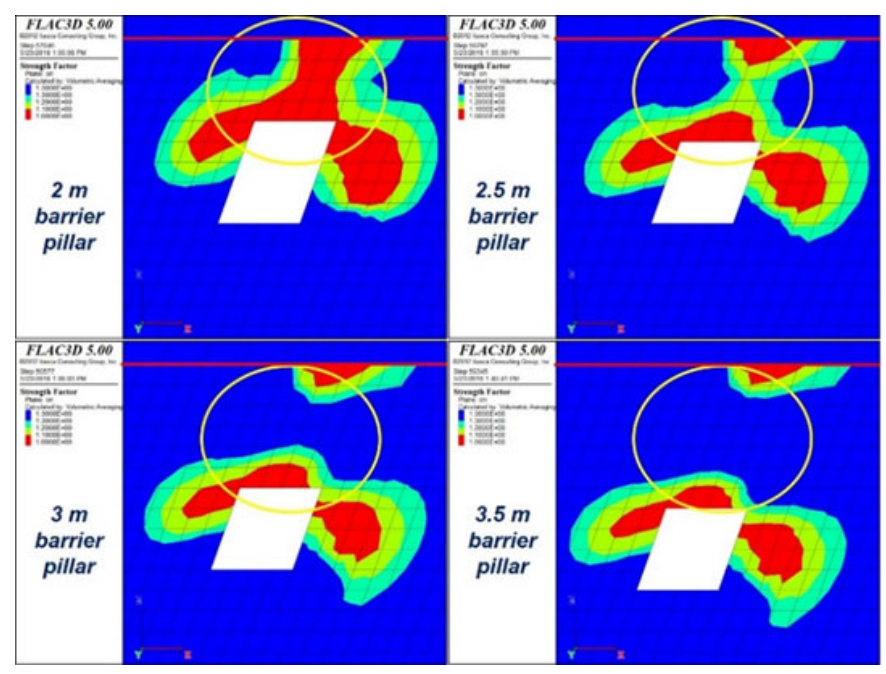

Fig. 18. Contour color of unstable area with different pillar heights. 


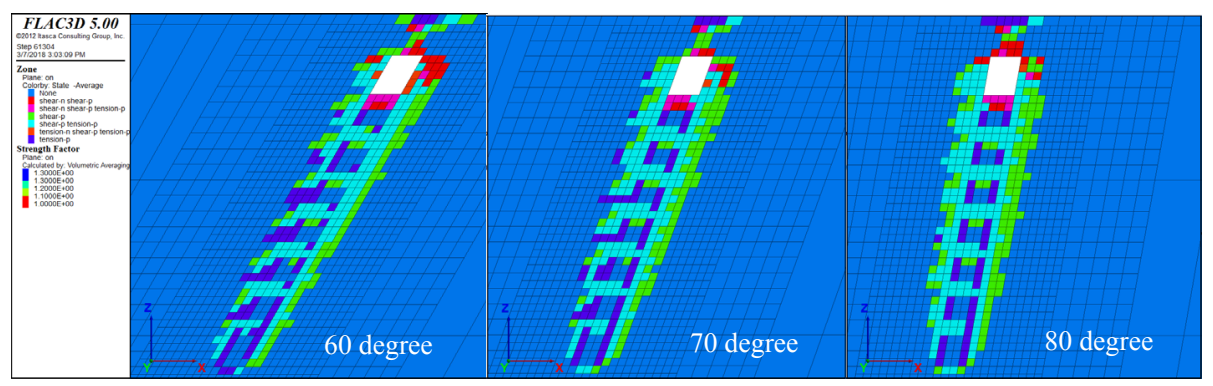

Fig. 19. Failure zones around the stope due to various vein dips.

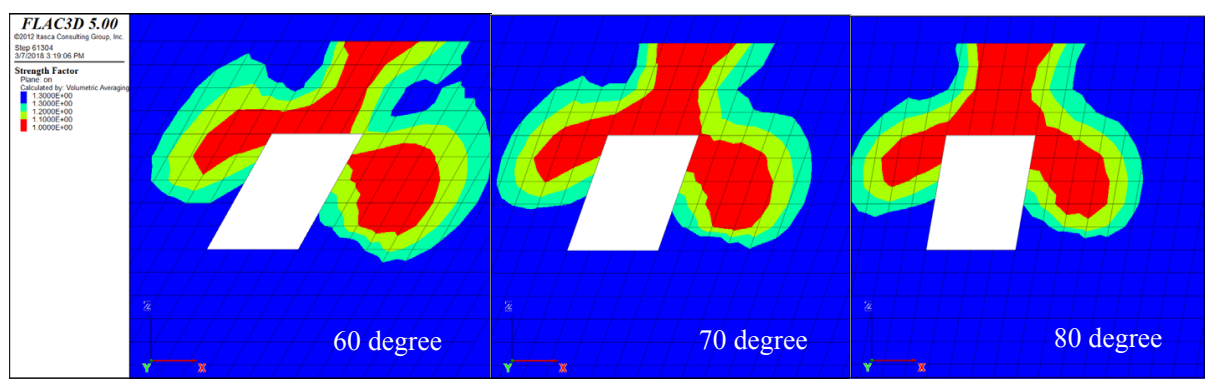

Fig. 20. Contour color of unstable regions around the stope due to various vein dips.

\section{Conclusion}

As NPGPGL underground gold mine will continue to deeper regions for the redevelopment of rest gold deposit, the potential impacts from the overlaying minedout regions to the new stope opening should be examined in order to stabilize the stope and barrier pillar in various mine conditions. Risk-index such as rock fracture, effect of underground water, weathering and stress redistribution of previous minedout area, etc. will be subjected to the current stope mining activities. In this study, the stability of stope and barrier pillar of new opening under the effects of previous mined-out regions are investigated numerically with three-dimensional finite difference code software, FLAC 3D. The analysis results indicated that the failure zone and instability of the surrounding rock mass of stope are increasing steadily as the stope progressing move towards upper slices and it will propagated to the previous mine out regions. These conditions should be paid attention for underground mining under previous mining activities for the safety working environment. Additionally, the instability of the barrier pillar between the top stope and overlaying mined-out regions became more severe when the model is simulated with the effect of previous mined-out regions. This result suggested that the barrier pillar should be maintained at 
least $3 \mathrm{~m}$ height in order to make sure to stabilize the stope and to prevent rock falls from the stope's roof and walls. Furthermore, based on the simulations with various vein dips, the results highlight that the failure conditions especially in hanging wall and foot wall are more likely to occur with low vein dip and it also increase above the stope opening as the vein dip increases. According to the above simulation results, suitable countermeasure arrangements is paramount to be prepared by considering the stability of stope mining activities under the effects of overlaying mined-out regions.

Acknowledgments. The authors would like to acknowledge Japan International Cooperation Agency (JICA) for supporting financial assistance of this research and field trip to mine site. The first author also wishes to express his appreciation to the managing director of NPGPGL gold mine for the permission of mine visit and rock samples.

\section{References}

1. Mitchell, A.H.G., Ausa, C.A., Deiparine, L., Hlaing, T., Htay, N. and Khine, A.: The Modi Taung-Nankwe gold district, Slate belt, central Myanmar: mesothermal veins in a Mesozoic orogeny. Journal of Asian Earth Sciences, 23 (2004) 321-341

2. Ivanhoe Myanmar Holding Limited: Production Sharing Proposal, Modi Taung Gold Project, Myanmar. Unpublished (2003)

3. Erskine, T.R.; Geology, Structure and Mineralization Characteristics of the Modi Taung Gold Deposit, Myanmar, Honours Thesis (2014)

4. Hoek, E., Kaiser, P.K. and Bawden. W.F.; Support of underground excavations in hard rock (2000) 